\title{
CADETS AND JUNIORS SUCCESS: HOW IMPORTANT IS IT FOR SPORTS CAREERS IN FREE-STYLE WRESTLING?
}

\author{
Mykola Latyshev \\ Borys Grinchenko Kyiv University, Ukraine, \\ Sergii Latyshev \\ Don State Technical University, Russian Federation \\ Aivars Kaupuzs \\ Rezekne Academy of Technologies, Latvia \\ Oleh Kvasnytsya \\ Khmelnytskyi National University, Ukraine \\ Yura Tropin \\ Kharkiv State Academy of Physical Culture, Ukraine \\ Irina Kvasnytsya \\ Khmelnytskyi National University, Ukraine \\ Volodimir Prystynskyi \\ Donbas State Pedagogical University, Ukraine
}

\begin{abstract}
The successful and effective management of sports training is impossible without the justified forecasting, which is adequate to the modern scientific knowledge. The forecasting creates the necessary preconditions for correct management decisions by athlete, coaches and administration. Nowadays, the discovery of talented athlete and the ways of their improvement are among the most discussed and popular directions in the athletes' training. The aim of the research -to analyze the significance of the success of wrestlers at the cadet and junior levels on the performance results during the senior career in relation to the weight classes. The sports careers of the medalists in freestyle wrestling of the Cadets and Junior European Championships have been studied. The analysis of the cadets' results demonstrates that more than $30 \%$ of the athletes have taken part in seniors competitions, but unfortunately only under $15 \%$ of the athletes have achieved success. At the same time, the juniors' results are better: about $60 \%$ of the athletes continued their sports careers at the senior level, but only approximately 25\% have achieved significant results. It is demonstrated that the athletes of the lightweight classes adapt faster to the senior wrestling and achieve success at the senior level. Keywords: analysis, cadets, juniors, results wrestling.
\end{abstract}




\section{Introduction and literature review}

The successful and effective management of sports training is impossible without the justified forecasting, which is adequate to the modern scientific knowledge. The forecasting creates the necessary preconditions for correct management decisions by athlete, coaches and administration. The setting of a definite promising goal is always connected to the forecasting of sport results (Bompa \& Haff, 2009; Bruce, Farrow \& Raynor, 2013; Platonov, 2015).

Nowadays, the discovery of talented athlete and the ways of their improvement are among the most discussed and popular directions in the athletes' training (Vaeyens, Lenoir, Williams, \& Philippaerts, 2008; Gulbin, Weissensteiner, Oldenziel, \& Gagné, 2013; Huxley, O'Connor, \& Larkin, 2017).

The most important success factors in sports include body build, conditioning, technical and tactical skills, mental abilities and the experience of a competitor (Kalina, 2000). In scientific papers the various factors, criteria and determinants of recognizing talented athlete have been considered. The essential qualities are: anthropometric measures (Veale, Pearce, Buttifant, \& Carlson, 2010); physical fitness (Mujika, Santisteban, Impellizzeri, \& Castagna, 2009; García-Pallarés, López-Gullón, Muriel, Díaz, \& Izquierdo, 2011), psychological measures andprofiles (Mirzaei, Curby, Rahmani-Nia, \& Moghadasi, 2009); gene influence - whether a person is born a champion or becomes it (Tucker \& Collins, 2012); success at competitions and career achievements (Hollings, Mallett, \& Hume, 2014; Brouwers, De Bosscher, \& Sotiriadou, 2012; Barreiros \& Fonseca 2012; De Bosscher, Shibli, Westerbeek, \& Van Bottenburg, 2015; Li, De Bosscher, Pion, Weissensteiner, \& Vertonghen, 2018; Foss, Sinex, \& Chapman, 2019). Such complex approaches and multidisciplinary methods of talent identification (Reilly, Williams, Nevill, \& Franks, 2000; Abbott \& Collins, 2002) are also applied.

Sporting success is a result of demonstration of all the qualities of the person and may be considered as an integrated parameter. In combat sports the victory is achieved as a result of a competition with other athlete, that is why the previous sporting success is one of the most objective parameter of the following success. The studies on identifying correlations between performance successes at various stages of preparation in combat sports such as judo (Julio et al., 2011; Barreiros, Côté, \& Fonseca, 2012), taekwondo (Sadowski, Gierczuk, Miller, Cieśliński, \& Buszta, 2012; Li et al., 2018), Greco-Roman wrestling (Korobeynikov \& Radchenko, 2009; Tropin, 2013; Biac, Hrvoje, \& Sprem, 2014; Karninčić, Baić, \& Sprem, 2017), free-style wrestling (Podlivaev, 2005; Latyshev et al., 2020) have been conducted. The weight classes in combat sports are of a significant importance, although we have not found the studies which would show 
the dependence of the results at the junior and cadet levels on the results at the senior level in relation to the weight classes.

Aim of research - to analyze the significance of the success of wrestlers at the cadet and junior levels on the performance results during the senior career in relation to the weight classes.

\section{Material and methods}

We have studied the sports careers of the medalists (winning $1^{\text {st }}$ to $3^{\text {rd }}$ places) of Cadet and Junior European Championships.

Ninety-six international sporting biographies of all the medalists (winning $1^{\text {st }}$ to $3^{\text {rd }}$ places) in freestyle wrestling of the three Cadet European Championships (from 2003 to 2005) have been analyzed. They include 1224 athletes' results at the international competitions.

Eighty-eight international sporting careers of all the medalists (winning $1^{\text {st }}$ to $3^{\text {rd }}$ places) in freestyle wrestling of the three Junior European Championships (from 2006 to 2008) have been analyzed separately. They include 1977 athletes' results at the international competitions.

The data of the results has been taken from the official site of the "United World Wrestling” (unitedworldwrestling.org, 2019).

To clarify definitions, we mean that to achieve senior success is to win a medal (from $1^{\text {st }}$ to $3^{\text {rd }}$ places) at the European Championships (Senior European success) or at the World Championships and the Olympic Games (Senior World success). Participation implies participation in the European Championships, World Championships and the Olympic Games regardless of the taken place. The winners are athletes who took the first place, medalists are athletes who took $1^{\text {st }}$ to $3^{\text {rd }}$ places at the competitions.

All the weight classes have been divided into the three groups depending on the classes for the analysis. For cadets the lightweight group - 42kg, $46 \mathrm{~kg}, 50 \mathrm{~kg}$; middleweight - 54kg, 58kg, 63kg, 69kg; heavyweight- 76kg, 85kg, 100kg. For juniors the division into the groups has been done in the following way: the lightweight group - 50kg, 55kg, 60kg; middleweight - 66kg, 74kg, 84kg; heavyweight - 96kg, 120kg.

Two parameters have been considered additionally for each weight group: the average age of the first participation in the international competitions and the first success at the international arena.

Methods of the descriptive statistics have been used in the paper. The following features of the research results were calculated: percentage, mean and standard deviation. To work with data (sorting, grouping, mathematical analysis), we used the programming language Python (libraries NymPy, pandas). 


\section{Results of research and discussion}

First, the analysis of the performances of the athletes who have achieved success at the cadet level has been conducted. Out of all the medalists among the cadets: 51 (53.1\%) athletes participated at the junior level and 32 (33.3\%) athletes achieved success at the given age stage.

Table 1 demonstrates the achievement of athletes' performances during the senior career in relation to the performance results at the competitions at the cadet level.

Table 1 Number and percentage of the performance results of the medalists and the winners of the Cadets European Championships at the senior level

\begin{tabular}{|l|c|c|c|}
\hline & $\begin{array}{c}\text { Senior } \\
\text { participation }\end{array}$ & $\begin{array}{c}\text { Senior } \\
\text { European success }\end{array}$ & $\begin{array}{c}\text { Senior } \\
\text { World success }\end{array}$ \\
\hline $\begin{array}{l}\text { Medalists of the Cadets } \\
\begin{array}{l}\text { European Championships, } \\
1-3 \text { places(n=96) }\end{array}\end{array}$ & $31(32.3 \%)$ & $12(12.5 \%)$ & $9(9.4 \%)$ \\
\hline $\begin{array}{l}\text { Winners of the Cadets } \\
\text { European Championships, } \\
\text { the 1st place(n=30) }\end{array}$ & $14(46.7 \%)$ & $10(33.3 \%)$ & $7(23.3 \%)$ \\
\hline
\end{tabular}

The analysis of the results in Table 1 demonstrates that only about one third of the medalists (32.3\%) and a half of the winners (46.7\%) of the Cadets European Championships have taken part in the senior international competitions. Furthermore, the percent of the athletes who have achieved the result at the senior level is higher among the winners than that among the medalists more than two times. It is shown that only about $10 \%$ of the successful athletes of the cadet level achieve success at the senior level.

The successes of the athletes' performances depending on their weight classes are presented in Table 2.

Table 2 Number and percentage of performance results of the medalists of the Cadets European Championships at the senior level depending on the weight groups

\begin{tabular}{|c|c|c|c|}
\hline Weight group & $\begin{array}{c}\text { Senior } \\
\text { participation }\end{array}$ & $\begin{array}{c}\text { Senior } \\
\text { European success }\end{array}$ & $\begin{array}{c}\text { Senior } \\
\text { World success }\end{array}$ \\
\hline Lightweight $(\mathrm{n}=27)$ & $9(33.3 \%)$ & $6(22.2 \%)$ & $4(14.8 \%)$ \\
\hline Middleweight $(\mathrm{n}=40)$ & $14(35.0 \%)$ & $3(7.5 \%)$ & $3(7.5 \%)$ \\
\hline Heavyweight $(\mathrm{n}=29)$ & $8(27.6 \%)$ & $3(10.3 \%)$ & $2(6.9 \%)$ \\
\hline
\end{tabular}

The percent of the athletes who participated in the competitions at the senior level scarcely depend on the weight class (about 30\%). At the same time, the percent of wrestlers who have achieved success is almost twice as high for the 
wrestlers of the lightweight group than that of the wrestlers of middleweight and heavyweight groups regardless of the competition rank.

Next, we will consider the performance results of the athletes who have achieved success at the junior level. Out of 88 athletes only about a half of the athletes (55.7\%) took part in the cadet level competitions and less than 30\% achieved success.

Table 3 provides the information concerning the Juniors European Championships medalists and winners.

Table 3 Number and percentage of performance results of the medalists and the winners of the Junior European Championships at the senior level

\begin{tabular}{|c|c|c|c|}
\hline & $\begin{array}{c}\text { Senior } \\
\text { participation }\end{array}$ & $\begin{array}{c}\text { Senior } \\
\text { European success }\end{array}$ & $\begin{array}{c}\text { Senior } \\
\text { World success }\end{array}$ \\
\hline $\begin{array}{c}\text { Medalists of the Junior } \\
\text { European Championships, } \\
1-3 \text { places(n=88) }\end{array}$ & $52(62.5 \%)$ & $20(22.7 \%)$ & $12(13.6 \%)$ \\
\hline $\begin{array}{c}\text { Winners of the Junior } \\
\text { European Championships, } \\
\text { the 1st place(n=26) }\end{array}$ & $20(76.9 \%)$ & $9(34.6 \%)$ & $6(23.1 \%)$ \\
\hline
\end{tabular}

More than $60 \%$ of the medalists and more than $75 \%$ of the winners continued their international sports careers at the senior level. Considering the athletes who continued their careers at the senior level such results have been obtained: about $40 \%$ (38.5\% of the medalists and $45 \%$ of the winners at the junior level) achieved the results at the European arena and $25 \%$ at the world one. There is a difference in the following career among the medalists and the winners of the Junior European Championships, nevertheless it is not as prominent in comparison with the successful cadets.

Table 4 presents a percentage and a number of junior athletes who continued performances and achieved success at the senior level.

Table 4 Number and percentage of performance results of the medalists of the Junior European Championships at the senior level depending on weight groups

\begin{tabular}{|l|c|c|c|}
\hline \multicolumn{1}{|c|}{ Weight group } & Senior participation & $\begin{array}{c}\text { Senior } \\
\text { European success }\end{array}$ & $\begin{array}{c}\text { Senior } \\
\text { World success }\end{array}$ \\
\hline Lightweight(n=31) & $20(64.5 \%)$ & $10(32.3 \%)$ & $4(12.9 \%)$ \\
\hline Middleweight $(\mathrm{n}=34)$ & $20(58.8 \%)$ & $4(11.8 \%)$ & $4(11.8 \%)$ \\
\hline Heavyweight $(\mathrm{n}=23)$ & $12(52.2 \%)$ & $6(26.1 \%)$ & $4(17.4 \%)$ \\
\hline
\end{tabular}

The following tendency can be noticed there: the higher the weight class, the less athletes continue their senior career at the international level. More athletes of the light weight and heavyweight groups achieved success at the European 
level. A correlation between success and a weight group has not been revealed for the world arena, the percentage of the athletes who have achieved success varies between $11 \%$ and $18 \%$. However it is worth noticing that in general there is quite a low number of athletes of the heavyweight group - only 12 persons, that is why it is possibly not a relevant statistical data.

Comparing the obtained data with the data on the athletes of track-and-field athletics - a sport with a metric measurement system of the result (Hollings \& Hume, 2010): only 46\%of athletes among the medalists of junior competitions have continued their careers at the senior level, which is significantly lower comparing to the obtained data (62.5\%) for wrestlers. At the same time $34 \%$ of the athletes of the track-and-field athletics achieved success (became winners or finalists at the international competitions) while this index for wrestlers is lower$22.7 \%$ at the European arena and $13.6 \%$ at the world level.

Considering the retrospective analysis, the significance of the junior success among the Olympic champions (Latyshev et al., 2020) is demonstrated: 41 wrestling careers of the Olympic gold medalists from 1996 to 2016has been analyzed. Twenty (48.8\%) out of 41 Olympic wrestling gold medalists had started their international career before they turned 18 years (cadets age). During the junior age 35 (85.4\%) out of 41 wrestlers participated in the continental or the world championship.

The next step of the analysis of the athlete's career has been estimating the age of achieving results in a senior career. These parameters are important for planning of the training process of athlete. They provide knowledge concerning how much time one needs for the adaptation to the senior sporting activities and how much time one needs for achieving result.

The athletes, who achieved success at the cadet level, participate at the senior level at the international arena for the first time at $22.4 \pm 2.6$ years on the average, while they achieve their first success at $23.4 \pm 3.3$ years.

Figure 1 demonstrates the average age of the first participation and success at the senior level depending on the weight group for the athletes who achieved success at the cadet level.

The figure clearly observes that the heavier the weight of the athlete the greater the age of the beginning of the performance at the international arena and the age of achieving the first success. The period between the first performance and the success is about a year (1.0 and 0.9 of a year) for the lightweight and middle weight groups correspondingly. At the same time, it is 1.5 year for the athletes of the heavyweight group.

Among the wrestlers who achieved success at the junior level the average age of the beginning of the performance at the senior level at the international arena is $22 \pm 2.9$ years, and the age of achieving results $-23.3 \pm 2.7$ years. The period between the first performance and achieving success is 1.3 year. 


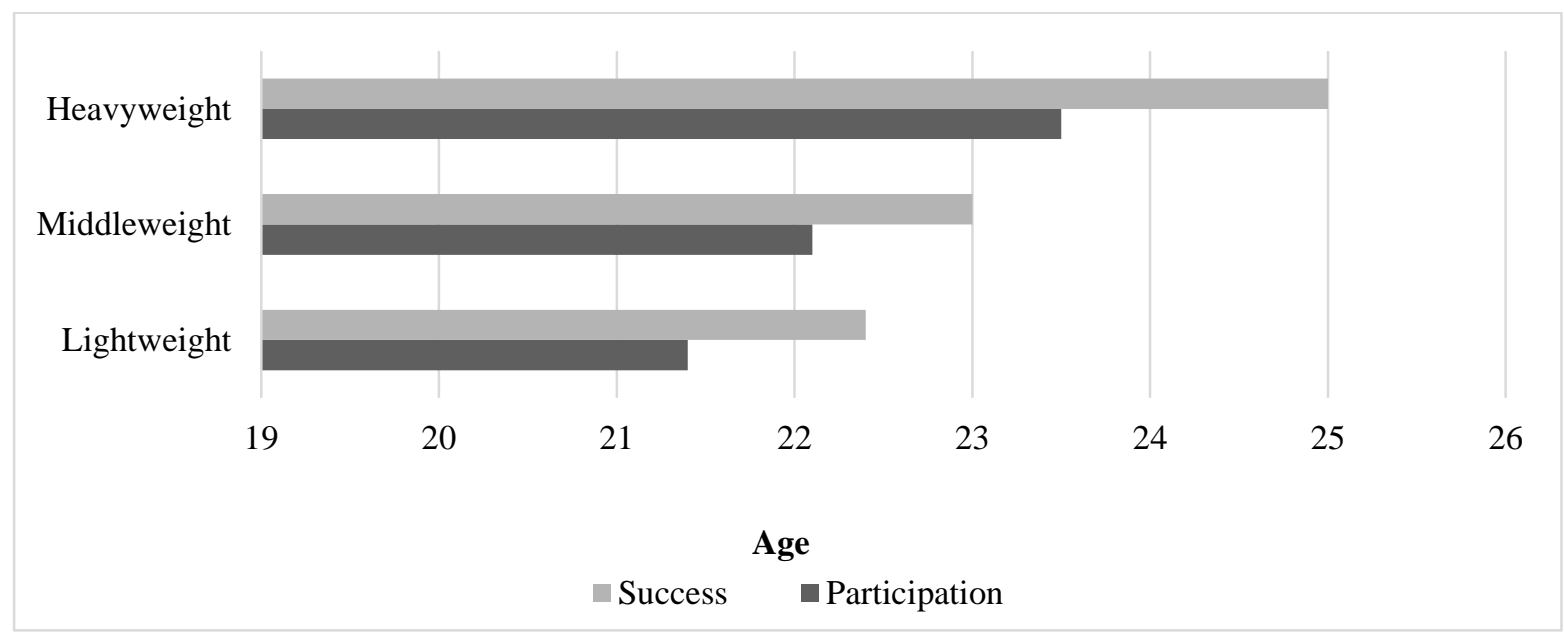

Figure 1 The average age of the first participation and first success at the senior level at the international competitions of the athletes who were medalists at the Cadet European championships

Figure 2 shows the average age of the first participation and success at the senior level depending on the weight group for the athletes who achieved success at the junior level.

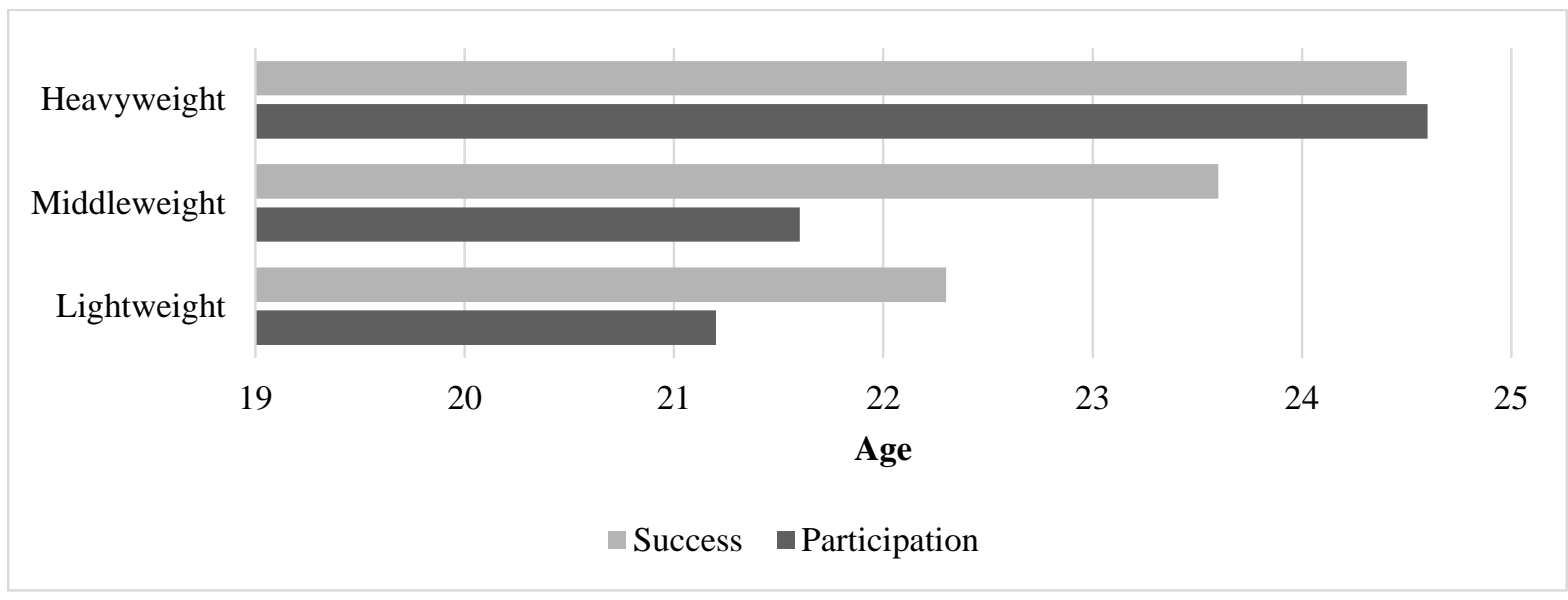

Figure 2 The average age of the first participation and first success at the senior level at the international competitions of the athletes who were medalists at the Junior European championships

For the lightweight wrestlers the time for adaptation is the shortest - the average age of the first participation is $21.2 \pm 1.8$ years. The period to the achievement of the first success is 1.1 year. For the middleweight wrestlers the period between the average age of the first participation and the first success equals 2 years. The heavyweight wrestlers almost simultaneously reach the age of achieving success and participation, however it takes place after reaching the age of 24 years. 
The acquired data indicates that the lightweight wrestlers almost immediately after performances at the junior level are able to compete at the high level at the national championship, which gives them the possibility to perform at the international arena. Moreover, by the age of 22-23yearsthey already achieve international success. For the middleweight wrestlers the adaptation for the senior wrestling takes more time and achievement of success takes place by the age of 23-24 years, while for the heavyweight group it is even later - by the age of 25 years.

\section{Conclusion}

The perspective analysis of the successful cadets and juniors has been conducted. The analysis has demonstrated that the importance of the junior achievements is significantly higher than that of the cadet ones. $62.5 \%$ of the junior medalists continued their career at the senior level, while only $32.3 \%$ of the cadet medalists had the experience of performance at the senior international competitions. The success of the juniors, who were medalists at the championships, is also higher: more than $20 \%$ achieved success at the senior European championships. Among the cadets only $12.5 \%$ achieved success at the senior European level. The wrestlers of lighter weight classes achieve success notably earlier than the athletes of heavier weight classes.

\section{References}

Abbott, A., \& Collins, D. (2002). A Theoretical and Empirical Analysis of a 'State of the Art' Talent Identification Model. High Ability Studies, 13(2), 157-178. DOI: $10.1080 / 1359813022000048798$

Biac, M., Hrvoje, K., \&Sprem, D. (2014). Beginning age, wrestling experience and wrestling peak performance-trends in period 2002-2012. Kinesiology, 46(S-1), 94-100.

Barreiros, A., \& Fonseca, A.M. (2012). A retrospective analysis of Portuguese elite athletes' involvement in international competitions. International Journal of Sports Science \& Coaching, 7(3), 593-600.

Barreiros, A., Côté, J., \& Fonseca, A.M. (2012). From early to adult sport success: Analysing athletes' progression in national squads. European Journal of Sport Science, 1-5. DOI: 10.1080/17461391.2012.671368

Bompa, T., \& Haff, G. (2009). Periodization training: Theory and methodology (5th ed.), Champaign, IL: Human Kinetics.

Brouwers, J., De Bosscher, V., \& Sotiriadou, P. (2012). An examination of the importance of performances in youth and junior competition as an indicator of later success in tennis. Sport Management Review, 15(4), 461-475. DOI: 10.1016/j.smr.2012.05.002

Bruce, L., Farrow, D., \& Raynor, A. (2013). Performance mile-stones in the development of expertise: Are they critical? Journal of Applied Sport Psychology, 25, 281-297. DOI: 10.1080/10413200.2012.725704 
Database. United World Wrestling. Unitedworldwrestling.org. 2019 [cited 10 December 2019]. Retrieved from https://unitedworldwrestling.org/database

De Bosscher, V., Shibli, S., Westerbeek, H., \& Van Bottenburg, M. (2015). Successful elite sport policies. An international comparison of the Sports Policy factors Leading to International Sporting Success. Aachen: Meyer \& Meyer.

Foss, J., Sinex, J., \& Chapman, R. (2019). Career Performance Progressions of Junior and Senior Elite Track and Field Athletes. Journal of Science in Sport and Exercise, 1, 168175. DOI:10.1007/s42978-019-0013-8

García-Pallarés, J., López-Gullón, J.M., Muriel, X., Díaz, A., \& Izquierdo, M. (2011). Physical fitness factors to predict male Olympic wrestling performance. European Journal of Applied Physiology, 111(8), 1747-1758. DOI:10.1007/s00421-010-1809-8

Gulbin, J., Weissensteiner, J., Oldenziel, K., \& Gagné F. (2013). Patterns of performance development in elite athletes. European Journal of Sport Science, 13(6), 605-614.

Hollings, S.C., \& Hume, P.A. (2010). Is Success at the World Junior Athletics Championships a Prerequisite for Success at World Senior Championships or Olympic Games? Prospective and Retrospective Analyses. New Studies in Athletics, 25(2), 65-77.

Hollings, S., Mallett, C., \& Hume, P. (2014). The transition from elite junior track-and-field athlete to successful senior athlete: Why some do, why others don't. International Journal of Sports Science and Coaching, 9, 457-472. DOI:10.1260/1747-9541.9.3.457

Huxley, D.J., O'Connor, D., \& Larkin, P. (2017). The pathway to the top: Key factors and influences in the development of Australian Olympic and World Championship track and field athletes. International Journal of Sports Science \& Coaching, 12(2), 264-275. DOI:10.1177/1747954117694738

Julio, U.F., Takito, M.Y., Mazzei, L., Miarka B., Sterkowicz, S., \& Franchini, E. (2011). Tracking 10-year competitive winning performance of judo athletes across age groups. Percept Mot Skills, 113(1) 139-149.

Kalina, R.M. (2000). Teoria sportów walki. Warszawa: Centralny Ośrodek Sportu.

Karninčić, H., Baić, M., \& Sprem, D. (2017). Optimal Age to Begin with Greco-Roman Wrestling and Reach Peak Performance Trends in Cases of World-Class Medal Winners of Various Weight Groups. Paper presented at the Conference Applicable Research in Wrestling. Novi Sad. Srbija.

Korobeynikov, G.V., \& Radchenko, Y.A. (2009). Modern competitive activities in the GrecoRoman wrestling (based on the performance of the national team of Ukraine at the 2008 European Championship). Theory and methods of physical education and sport, 2, 56-58.

Latyshev, M., Latyshev, S., Korobeynikov, G., Kvasnytsya, O., Shandrygos, V., \& Dutchak, Y. (2020). The analysis of the results of the Olympic free-style wrestling champions. Journal of Human Sport and Exercise, 15(2), in press. DOI: https://doi.org/ 10.14198/jhse.2020.152.14

Li, P., De Bosscher, V., Pion, J., Weissensteiner, J.R., \& Vertonghen, J. (2018). Is international junior success a reliable predictor for international senior success in elite combat sports? European journal of sport science, 18(4), 550-559.

Mirzaei B., Curby D., Rahmani-Nia F., \& Moghadasi, M. (2009). Physiological profile of elite Iranian junior freestyle wrestlers. The Journal of Strength \& Conditioning Research, 2009, 23(8), 2339-2344.

Mujika, I., Santisteban, J., Impellizzeri, F.M., \& Castagna, C. (2009). Fitness determinants of success in men's and women's football. Journal of sports sciences, 27(2), 107-114. DOI: https://doi.org/10.1080/02640410802428071 
Platonov, V.N. (2015). System of athletes' preparation in the Olympic sport. General theory and its practical applications. Olympic literature.

Podlivaev, B.A. (2005). Freestyle wrestling at the XXVII Olympic Games in Athens. Theory and practice of physical culture and sports, 3, 28-30.

Reilly, T., Williams, A.M., Nevill, A., \& Franks, A. (2000). A multidisciplinary approach to talent identification in soccer. Journal of Sports Sciences, 18(9), 695-702. DOI: 10.1080/02640410050120078

Sadowski, J., Gierczuk, D., Miller, J., Cieslinski, I., \& Buszta, M. (2012). Success factors in male WTF taekwondo juniors. J Combat Sports Martial Arts, 1, 47-51.

Tropin, Y. (2013). Comparative analysis of technical and tactical preparedness Greco-Roman style wrestler at the Olympic Games-2008 and the Olympic Games-2012. Physical education of students, 4, 92-96.

Tucker, R., \& Collins, M. (2012). What makes champions? A review of the relative contribution of genes and training to sporting success. British Journal of Sports Medicine, 46, 555-561.

Vaeyens, R., Lenoir, M., Williams, A.M., \& Philippaerts, R.M. (2008). Talent Identification and Development Programmes in Sport: Current Models and Future Directions. Sports Medicine, 38(9), 703-714.

Veale, J., Pearce, A., Buttifant, D., \& Carlson, J. (2010). Anthropometric Profiling of Elite Junior and Senior Australian Football Players. International Journal of Sports Physiology and Performance, 5(4), 509-520. DOI: https://doi.org/10.1123/ijspp.5.4.509 